(C) Є.С. Сірчак, В.І. Грига, А.В. Стегура, Й.І. Пічкар, 2019

УдК: 616.36-003.826:616.379-008.64:616-008.83:547.477

\title{
Зміна рівнів амінокислот сироватки крові у хворих на неалкогольну жирову хворобу печінки та цукровий діабет 2 типу
}

\author{
Є.С. Сірчак ${ }^{1}$, В.І. Грига ${ }^{1}$, А.В. Стегура ${ }^{1}$, Й.І. Пічкар ${ }^{2}$ \\ e-mail: sirchakliza777@gmail.com
} Ужсгородський національний університет; медичний факультет; ${ }^{1}$ кафедра пропедевтики
внутрішніх хвороб; ${ }^{2}$ кафедра госпітальної терапї, Ужгород

\section{Реферат}

Вступ. Сучасний пацієнт - це хворий із коморбідним, поліморбідним фоном. На сьогодні доведено спільність патогенетичних механізмів для неалкогольної жирової хвороби печінки (НАЖХП) та метаболічного синдрому і стає очевидним їх зв'язок із цукровим діабетом (ЦД) 2 типу, серцево-судинними захворюваннями.

Мета дослідження: дослідити зміни рівнів амінокислот (АК) сироватки крові у хворих на НАЖХП та ЦД 2 типу.

Матеріали та методи. Обстежено 76 хворих на НАЖХП та ЦД 2 типу. Пацієнтів поділили на групи, а саме: в I підгрупу увійшло 36 хворих на неалкогольний жировий гепатоз (НАЖГ); II підгрупу склали 40 хворих на неалкогольний стеатогепатит (НАСГ). Усі обстежені пацієнти підлягали дослідженню за загальноклінічними, антропометричними, інструментальними та лабораторними методами. Проведено кількісне визначення рівня вільних АК у сироватці крові, проводили за методом обернено-фазової високоефективної рідинної хроматографії в ізократичному режимі елюювання з електрохімічним детектуванням.

Результати досліджень та їх обговорення. Аналіз показників білкового обміну вказує на зменшення кількості загального білка у сироватці крові переважно у хворих II групи, що супроводжувалось диспротеїнемією. Встановлено переважне зменшення рівнів вільних АК сироватки крові у обох груп обстежених пацієнтів. При цьому більш суттєве відхилення від норми встановлено у ІІ групі пацієнтів, а саме - зменшення рівнів триптофану, тирозину, метіоніну, лейцину, аргініну $(\mathrm{p}<0,01)$, а також незначне зменшення вмісту аланіну, треоніну, серину, лізину ( $>0,05)$. Ці зміни супроводжувались статистично достовірним збільшенням рівнів цистеїну, а також показників глутаміну, аспарагіну, фенілаланіну, валіну (p>0,05). Ідентичні, але менш виражені зміни встановлено і в групі хворих з НАЖГ та ЦД 2 типу.

Висновки. 1. У хворих на НАЖХП та ЦД 2 типу встановлено диспротеїнемія у сироватці крові із переважним збільшенням рівня $\alpha_{2}$ - та $\gamma$-глобулінів. 2. Зміни рівнів вільних АК у сироватці крові у хворих на НАЖХП та ЦД 2 типу проявляються зменшенням показників триптофану, тирозину, метіоніну, лейцину, аргініну, а також збільшенням концентрації цистеїну, проліну, валіну, глутаміну. Ці зміни більш в иражені у пацієнтів на ЦД 2 типу із ураженням печінки на стадії НАСГ, ніж НАЖГ.

Ключові слова: цукровий діабет 2 типу, неалкогольна жирова хвороба печінки, неалкогольний жировий гепатоз, неалкогольний стеатогепатит, амінокислоти.

Changes of amino acid levels in serum in patients with non-alcoholic fatty liver disease and type 2 diabetes Ye.S. Sirchak ${ }^{1}$, V.I. Griga ${ }^{1}$, A.V. Stegura ${ }^{1}$, Yo.I. Pichkar ${ }^{2}$

Uzhhorod National University, faculty of medicine, ${ }^{1}$ Department of propaedeutics of internal diseases, ${ }^{2}$ Department of Hospital Therapy, Uzhhorod

\section{Abstract}

Introduction. The modern patient is a patient with a comorbid, polymorphic background. Today, the community of pathogenetic mechanisms for non-alcoholic fatty liver disease (NAFLD) and metabolic syndrome has been proven and their association with type 2 diabetes mellitus and cardiovascular disease is becoming apparent.

The purpose of the study - to investigate changes in serum amino acid (AK) levels in patients with NAFLD and type 2 diabetes.

Materials and methods of research. 76 patients with NAFLD and type 2 diabetes were examined. The patients were divided into groups, namely: in the I subgroup were 36 patients with non-alcoholic fat liver disease (NAFLD); The second subgroup was 40 patients with non-alcoholic steatohepatitis (NASH). All patients examined were subjected to general clinical, anthropometric, instrumental and laboratory testing. Quantitative determination of the level of free $\mathrm{AK}$ in serum was performed by the method of reversed-phase high-performance liquid chromatography in isocratic mode of elution with electrochemical detection.

Results and Discussion. The analysis of protein metabolism indicates a decrease in the amount of total protein in the serum mainly in patients of group II, accompanied by dysproteinemia. There was a predominant decrease in serum free AK levels in both groups of patients. However, a more significant deviation from the norm was established in the second group of patients, namely a decrease in levels of tryptophan, tyrosine, methionine, leucine, arginine $(p<0.01)$, as well as a slight decrease in the content of alanine, threonine, serine, lysine $(p>0.05)$. These changes were accompanied by statistically significant increases in cysteine levels, as well as glutamine, asparagine, phenylalanine, valine ( $>0.05$ ). Identical but less pronounced changes were found in the group of patients with NAFLD and type 2 diabetes.

Conclusions. 1. Patients with NAFLD and type 2 diabetes have serum dysproteinemia with a predominant increase in $\alpha 2$ - and $\gamma$ globulin levels. 2. Changes in serum free levels of AK in patients with NAFLD and type 2 diabetes are manifested by a decrease in tryptophan, tyrosine, methionine, leucine, arginine, as well as an increase in cysteine, proline, valine, and glutamine concentrations. These changes are more expressed in patients with type 2 diabetes mellitus with NASH than with NAFG.

Key words: diabetes mellitus type 2, non-alcoholic fatty liver disease, non-alcoholic fatty hepatosis, non-alcoholic steatohepatitis, amino acids. 
Вступ. Тепер є всесвітня епідемія неінфекційних захворювань, таких як серцево-судинні патології, цукровий діабет (ЦД) 2 типу, ожиріння, неалкогольна жирова хвороба печінки (НАЖХП) тощо [1]. Сучасний пацієнт - це хворий із коморбідним, поліморбідним фоном.

Поняття НАЖХП включає дві морфологічні форми захворювання: неалкогольний жировий гепатоз (НАЖГ) і неалкогольний стеатогепатит (НАСГ). Важкість захворювання при НАСГ досить варіабельна, включно з фіброзом, цирозом ЦП) і гепатоцелюлярною карциномою [2, 3, 4]. Незважаючи на маску «нешкідливого» захворювання, у 12-40\% хворих із простим стеатозом протягом 8-13 років формується НАСГ, у половини з них розвивається прогресуючий фіброз і у 1/6 - ЦП [5].

НАЖХП охоплює спектр захворювань, тісно пов'язаних із метаболічними факторами ризику. На сьогодні доведено спільність патогенетичних механізмів для НАЖХП та метаболічного синдрому i стає очевидним їх зв'язок із ЦД 2 типу, серцевосудинними захворюваннями тощо [6, 7]. Відомо, що у хворих ЦД порушуються всі види обмінних процесів в організмі, і в тій чи іншій мірі страждають всі органи і системи. Отже, на фоні порушеного обміну речовин при ЦД 2 типу у поєднанні 3 НАЖХП у пацієнтів виникають глибокі зміни метаболічних реакцій і стає очевидним факт порушення рівнів різних біологічно активних сполук в організмі, в тому числі й амінокислот, що вимагає подальшого дослідження.

Мета дослідження: дослідити зміни рівнів амінокислот сироватки крові (АСК) у хворих на НАЖХП та ЦД 2 типу.

Наукове дослідження $є$ фрагметном держбюджетної теми кафедри хірургічних хвороб та кафедри пропедевтики внутрішніх хвороб медичного факультету ДВНЗ «УжНУ» № 851 «Механізми формування ускладнень при захворюваннях печінки та підшлункової залози, методи їх лікування та профілактики», номер державної реєстрації: 0115U001103), а також наукової теми кафедри пропедевтики внутрішніх хвороб «Поліморбідна патологія при захворюваннях органів травлення, особливості патогенезу, можливості корекції (номер державної реєстрації 0118U004365).

Матеріали та методи. На клінічній базі кафедри пропедевтики внутрішніх хвороб медичного факультету ДВНЗ «УжНУ» (гастроентерологічне та ендокринологічне відділення ЗОКЛ ім. А. Новака) за 2016-2019 рр. обстежено 76 хворих на НАЖХП та ЦД 2 типу. Пацієнтів поділили на групи, а саме: в I підгрупу ввійшло 36 хворих на неалкогольний жировий гепатоз (НАЖГ) (серед них чоловіків було 20 (55,6 \%), жінок 16 (44,4 \%), середній вік становив $48,3 \pm 5,5$ року); II підгрупу склали 40 хворих на неалкогольний стеатогепатит (НАСГ) (серед них чоловіків було 24 (61,6 \%), жінок 16 (40,0\%; середній вік становив 47,8 7,,2 років).
У контрольну групу ввійшло 20 практично здорових осіб (чоловіків було $12(60,0 \%)$, жінок -8 (40,0\%). Середній вік складав $47,6 \pm 5,8$ року.

Усі дослідження були виконані за згодою пацієнтів (від усіх хворих було отримано письмову згоду щодо проведення відповідних діагностичнолікувальних заходів), а методика їх проведення відповідала Гельсінській декларації прав людини 1975 p. та iii перегляду 1983 р., Конвенції Ради Свропи про права людини і біомедицину та законодавства України.

Усі обстежені пацієнти підлягали дослідженню за загальноклінічними, антропометричними, інструментальними та лабораторними методами. Для верифікації діагнозу звертали увагу, на характер скарг, анамнез захворювання. При антропометричному дослідженні визначали зріст, вагу обвід талії, а також розраховували індекс маси тіла (IMT). Усім хворим виконано ультразвукове дослідження органів черевної порожнини за загальноприйнятою методикою. У сироватці крові проведено стандартні загальні та біохімічні дослідження.

Кількісне визначення рівня вільних амінокислот (АК) у сироватці крові проводили за методом обернено-фазової високоефективної рідинної хроматографії в ізократичному режимі елюювання $з$ електрохімічним детектуванням (I. Н. Краснова та інші, 2000 р.). Для хроматографії використовували рідинний хроматограф («Міліхром», Росія) 3 електрохімічним детектором [8].

Діагноз НАЖХП встановили згідно $з$ критеріями уніфікованого клінічного протоколу (наказ МO3 України від 06.11.2014 р. № 826) та клінічними рекомендаціями EASL-EASD-EASO щодо діагностики та лікування НАЖХП. Ступінь ураження печінки розраховано з використанням сурогатних маркерів фіброзу за допомогою онлайн-калькуляторів NAFLD fibrosis score (NFS), Fibrosis 4 calculator (FIB-4), а також фібротесту [2].

Діагноз ЦД 2 типу встановлено згідно з рекомендаціями IDF (2005 р.), а також із урахуванням критеріїв уніфікованого клінічного протоколу (наказ MO3 України від 21.12.2012 № 1118). Ступінь важкості ЦД 2 типу оцінювали за рівнем НbA1c (норма - до $6,0 \%)[9,10]$.

Аналіз і обробка результатів обстеження хворих здійснювалася за допомогою комп’ютерної програми STATISTICA 10.0 (фірми StatSoft Inc, USA) 3 використанням параметричних та непараметричних методів оцінки отриманих результатів.

Результати досліджень та їх обговорення. За результатами лабораторно-інструментальних методів дослідження у хворих на ЦД 2 типу встановлено зміни, характерні для стеатозу (I група обстежених) та стеатогепатиту (II група обстежених).

Аналіз показників білкового обміну вказує на зменшення кількості загального білка у сироватці крові переважно у хворих II групи. Диспротеїнемія у хворих ЦД 2 типу на НАСГ проявлялася зменшенням рівня альбуміну (до $35,1 \pm 1,2 \%-\mathrm{p}<0,05$ ) та 
підвищенням показників $\alpha_{2^{-}}$та $\gamma$-глобулінів (до $11,7 \pm 1,1 \%$ та до $23,8 \pm 0,8 \%-\mathrm{p}<0,05)$. У хворих на ЦД 2 типу та НАЖГ також встановлено тенденцію до зниження рівня загального білка та альбуміну в сироватці крові, що супроводжувалось підвищенням глобулінових фракцій ( $\alpha_{2}$ - та $\gamma$-глобулінів), поряд із цим різниця була статистично не достовірна. Результати наведені в таблиці 1.

Таблиця 1

Зміна показників білкового обміну сироватки крові в обстежених хворих на НАЖХП та ЦД 2 типу

\begin{tabular}{|c|c|c|c|}
\hline \multirow{3}{*}{ Показник } & \multirow{2}{*}{$\begin{array}{c}\text { Контрольна } \\
\text { група } \\
(\mathrm{n}=20)\end{array}$} & \multicolumn{2}{|c|}{$\begin{array}{c}\text { Обстежені хворі } \\
\text { на НАЖХП та ЦД } 2 \text { типу }\end{array}$} \\
\hline & & $\begin{array}{l}\text { I група }(\mathrm{n}=36) \\
\text { хворі з НАЖГ } \\
\text { та ЦД } 2 \text { типу }\end{array}$ & $\begin{array}{c}\text { II група }(\mathrm{n}=40) \\
\text { хворі з НАСГ та ЦД } 2 \\
\text { типу }\end{array}$ \\
\hline & $\mathrm{M} \pm \mathrm{m}$ & $\mathrm{M} \pm \mathrm{m}$ & $\mathrm{M} \pm \mathrm{m}$ \\
\hline Загальний білок (г/л) & $73,7 \pm 0,9$ & $67,3 \pm 1,1$ & $60,1 \pm 2,4 *$ \\
\hline - альбуміни (\%) & $46,2 \pm 1,1$ & $38,3 \pm 0,8$ & $35,1 \pm 1,2 *$ \\
\hline \multicolumn{4}{|l|}{ Глобуліни: } \\
\hline$-\alpha_{1}(\%)$ & $4,4 \pm 0,5$ & $4,6 \pm 0,8$ & $4,8 \pm 0,4$ \\
\hline$-\alpha_{2}(\%)$ & $6,5 \pm 0,7$ & $9,1 \pm 0,7$ & $11,7 \pm 1,1 *$ \\
\hline$-\beta(\%)$ & $10,2 \pm 0,9$ & $11,8 \pm 1,2$ & $13,7 \pm 1,2$ \\
\hline$-\gamma(\%)$ & $17,9 \pm 1,1$ & $18,3 \pm 0,5$ & $23,8 \pm 0,8 *$ \\
\hline
\end{tabular}

Примітка: показники у хворих достовірно відрізняються від таких показників контрольної групи: * - p $<0,05$.

Диспротеїнемія у сироватці крові супроводжувалася порушенням рівнів вільних АК сиро- ватки крові, особливо у хворих з НАСГ та ЦД 2 типу (II група). Результати наведені у таблиці 2.

Таблиця 2

Рівні вільних АК сироватки крові в обстежених хворих на НАЖХП та ЦД 2 типу і контрольної групи

\begin{tabular}{|c|c|c|c|}
\hline \multirow{3}{*}{$\begin{array}{c}\text { Амінокислоти } \\
\text { (нмоль/мл) }\end{array}$} & \multirow{2}{*}{$\begin{array}{c}\text { Контрольна } \\
\text { група } \\
(\mathrm{n}=20)\end{array}$} & \multicolumn{2}{|c|}{$\begin{array}{c}\text { Обстежені хворі } \\
\text { на НАЖХП та ЦД } 2 \text { типу }\end{array}$} \\
\hline & & $\begin{array}{c}\text { I група }(\mathrm{n}=36) \\
\text { хворі з НАЖГ та ЦД } 2 \text { типу }\end{array}$ & $\begin{array}{c}\text { II група }(\mathrm{n}=40) \\
\text { хворі на НАСГ та ЦД } 2 \text { типу }\end{array}$ \\
\hline & $\mathrm{M} \pm \mathrm{m}$ & $\mathrm{M} \pm \mathrm{m}$ & $\mathrm{M} \pm \mathrm{m}$ \\
\hline Цистеїн (Cys) & $177,15 \pm 11,15$ & $195,17 \pm 8,13$ & $221,41 \pm 11,56^{*}$ \\
\hline Орнітин (Orn) & $243,25 \pm 14,22$ & $254,56 \pm 10,12$ & $267,20 \pm 11,17$ \\
\hline Лізин (Lys) & $270,01 \pm 18,26$ & $263,16 \pm 7,99$ & $258,03 \pm 7,07$ \\
\hline Гістидін (His) & $88,30 \pm 12,07$ & $86,11 \pm 11,14$ & $87,24 \pm 7,13$ \\
\hline Аргінін (Arg) & $93,11 \pm 8,77$ & $62,15 \pm 4,76 *$ & $40,08 \pm 3,15 * *,+$ \\
\hline Аспарагін (Asp) & $8,44 \pm 0,76$ & $8,63 \pm 0,78$ & $8,99 \pm 0,61$ \\
\hline Серин (Ser) & $118,30 \pm 12,75$ & $113,70 \pm 10,09$ & $109,56 \pm 7,15$ \\
\hline Гліцин (Gly) & $276,15 \pm 14,33$ & $277,15 \pm 10,11$ & $275,06 \pm 14,10$ \\
\hline Глутамін (Gln) & $514,35 \pm 17,05$ & $522,45 \pm 11,03$ & $535,40 \pm 7,88$ \\
\hline Треонін (Thr) & $162,11 \pm 10,45$ & $156,23 \pm 8,89$ & $146,71 \pm 10,23$ \\
\hline Аланін (Ala) & $410,45 \pm 20,03$ & $408,09 \pm 13,16$ & $392,15 \pm 7,45$ \\
\hline Пролін (Pro) & $150,07 \pm 12,65$ & $156,00 \pm 9,67$ & $197,22 \pm 10,34 *,+$ \\
\hline Тирозин (Туг) & $60,09 \pm 2,05$ & $46,13 \pm 2,16 *$ & $30,15 \pm 3,23 * *,+$ \\
\hline Триптофан (Trp) & $57,66 \pm 3,42$ & $41,15 \pm 2,28 *$ & $29,05 \pm 2,45 * *,+$ \\
\hline Метіонін (Met) & $24,06 \pm 3,33$ & $14,01 \pm 1,24 *$ & $10,07 \pm 1,88 * *$ \\
\hline Валін (Val) & $218,19 \pm 15,26$ & $228,50 \pm 9,12$ & $244,41 \pm 10,13$ \\
\hline Фенілаланін (Phe) & $84,17 \pm 5,11$ & $86,33 \pm 4,14$ & $95,16 \pm 3,12$ \\
\hline Лейцин (Leu) & $123,11 \pm 7,85$ & $84,23 \pm 4,26 *$ & $60,77 \pm 2,89 * *$ \\
\hline Ізолейцин (ILeu) & $115,13 \pm 5,12$ & $100,08 \pm 4,77$ & $96,17 \pm 3,26^{*}$ \\
\hline
\end{tabular}

Примітка: показники у хворих достовірно відрізняються від таких показників контрольної групи: * $-\mathrm{p}<0,05 ; * *$ $-\mathrm{p}<0,01$; різниця між показниками у хворих I та II груп достовірні: $+-\mathrm{p}<0,05$.

Аналіз отриманих даних вказує на переважне зменшення рівнів вільних АК сироватки крові у обох груп обстежених пацієнтів. При цьому більш суттєве відхилення від норми встановлено у II групі пацієнтів, а саме - зменшення рівнів триптофану (до 29,05 $\pm 2,45$ нмоль/мл - p<0,01), тирозину 
(до 30,15 $\pm 3,23$ нмоль/мл - $\mathrm{p}<0,01$ ), метіоніну (до $10,07 \pm 1,88$ нмоль/мл - $\mathrm{p}<0,01$ ), лейцину (до $60,77 \pm 2,89$ нмоль/мл - $\mathrm{p}<0,05$ ), аргініну (до $40,08 \pm 3,15$ нмоль/мл - $<<0,01)$, а також незначне зменшення вмісту аланіну, треоніну, серину, лізину ( $>0,05)$. Ці зміни супроводжувались статистично достовірним збільшенням рівнів цистеїну (до $256,85 \pm 17,25$ нмоль/мл - $<<0,01$ ), проліну (до $286,12 \pm 16,11$ нмоль/мл - p<0,01), а також показників глутаміну, аспарагіну, фенілаланіну, валіну ( $>>0,05)$.

Ідентичні, але менш виражені зміни встановлено і в групі хворих із НАЖГ та ЦД 2 типу статистично достовірне зменшення рівня триптофану, тирозину, метіоніну, лейцину, аргініну $(\mathrm{p}<0,05)$ при незначному збільшенні рівня цистеїну, проліну, валіну, а також глутаміну, фенілаланіну, гліцину, орнітину.

Отже, у хворих на НАЖХП та ЦД 2 типу встановлено порушення синтетичної функції печінки, що проявляється зниженням рівня загального білка у сироватці крові. Амінокислотний дисбаланс, що виникає при метаболічно індукованих розладах у даних пацієнтів вимагає подальшого дослідження в даному напрямку для розуміння процесів, що відбуваються в організмі у хворих при НАЖХП та ЦД 2 типу.

Висновки. 1. У хворих на НАЖХП та ЦД 2 типу встановлена диспротеїнемія у сироватці крові із переважним збільшенням рівня $\alpha_{2}$ та $\gamma$-глобулінів.

2. Зміни рівнів вільних АК у сироватці крові у хворих на НАЖХП та ЦД 2 типу проявляються зменшенням показників триптофану, тирозину, метіоніну, лейцину, аргініну, а також збільшенням концентрації цистеїну, проліну, валіну, глутаміну. Ці зміни більш виражені у пацієнтів на ЦД 2 типу із ураженням печінки на стадії НАСГ, ніж НАЖГ.

Конфлікт інтересів: відсутній.

Інформація про фінансування. Автори не отримували ніяких винагород ні в якій формі від фірм-виробників лікарських препаратів, медичного обладнання та матеріалів, у тому числі конкурентів, здатних вплинути на результати роботи.

Особистий внесок кожного автора у виконання роботи:

Сірчак С.С. - концепція і дизайн дослідження.

Барані В.С. - збирання й обробка матеріалів, написання тексту.

Коваль В.Ю. - аналіз отриманих даних.

Фабрі 3.Й. - статистична обробка матеріалів.

\section{Список використаної літератури}

1. Pataia V, Papacleovoulou G, Nikolova V et al. Paternal cholestasis exacerbates obesity-associated hypertension in male offspring but is prevented by paternal ursodeoxycholic acid treatment. International Journal of Obesity. 2018; May: https://doi.org/10.1038/s41366-018-0095-0

2. European Association for the Study of the Liver (EASL), European Association for the Study of Diabetes (EASD) and European Association for the Study of Obesity (EASO) EASL-EASD-EASO Clinical Practice Guidelines for the management of non-alcoholic fatty liver disease. Journal of Hepatology. 2016; 64: 1388-1402. doi.org/10.1016/j.jhep.2015.11.004.

3. Ivaskin VT Diagnosis and treatment of nonalcoholic fatty liver disease: clinical recommendations. Moskva: MED-press-inform; 2015, 32 p. (in Russian)

4. Fadienko GD, Gridnyev AE Efficiency and safety of ademetionine in the correction of liver function in patients with steatohepatitis. The results of an open comparative post-marketing study. Gastroenterology. 2018; 52 (2): 27-34. (in Russian)

5. Dragomiretska NV, Zabolotna IB, Izha GM New potential of non-alcoholic fatty liver disease. Gastroenterology. 2014; 2 (52): 42-45. (in Russian)

6. Stepanov YuM, Nedzvetskaya NV, Yagmur VB, Klenina IA, Oshmyanskaya Nyu Noninvasive diagnosis of liver fibrosis in patients with nonalcoholic fatty liver disease. Gastroenterology. 2017; 51 (3): 188-195. doi: 10.22141/2308-2097.51.3.2017.112635 (in Ukrainian)

7. Stepanov YuM, Nedzvetskaya NV, Yagmur VB, Klenina IA Non-alcoholic fatty liver disease: features of metabolic changes at different stages of the disease. Gastroenterology. 2018; 52 (1): 13-18. doi: 10.22141/2308-2097.52.1.2018.130772 (in Ukrainian)

8. Krasnova IN, Karpova LA, Cherkas YuV Opredelenije aminokislot v sivorotke krovi cheloveka metodom obrachenno-fazovoj visokoeffektivnoj zhidkostnoj chromatografii $\mathrm{v}$ rezhime izokraticheskogo eljuirovanija. Zhurnal analiticheskoj chimii. 2000; 55 (1): 66-74.

9. Hobzej MK, Guljchij MV, Stepanenko AV et al. Type 2 Diabetes Mellitus. Unified clinical protocol for primary and secondary (specialized) medical care. Kijiv; 2012. 118 p. (in Ukrainian). http://ukrgastro.com.ua/klinichni-protokoli-ta-nastanovi/

10. Hobzej MK, Matyuha LF, Netjazhenko VZ et al. Type 2 Diabetes Mellitus. Adapted clinical guideline based on evidence. Kijiv; 2012. 343 p. (in Ukrainian). http://ukrgastro.com.ua/klinichni-protokoli-tanastanovi/

Стаття надійшла до редакції: 